\title{
Caracterización físico-mecánica y microscópica de áridos ligeros de cenizas volantes producidos en frío
}

\section{Physical, mechanical and microscopic characterization of cold bonded fly ash lightweight aggregates}

C. VIDELA, P. MARTÍNEZ

Departamento de Ingeniería y Gestión de la Construcción, Escuela de Ingeniería, Pontificia Universidad Católica de Chile. Escuela de Ingeniería de la Construcción, Universidad de Valparaiso

Fecha de recepción: 4-II-02

Fecha de aceptación: 8-IV-02

CHILE

\section{RESUMEN}

El estudio presenta los resultados obtenidos de ensayos realizados sobre áridos ligeros de cenizas volantes fabricados con tres tipos de conglomerantes: cal, cemento portland puro y' cemento portland puzolánico. El proceso de fabricación empleado para la elaboración de los áridos consistió en un sistema de aglomeración por agitación bajo condiciones de endurecimiento en frío. Los ensayos efectuados comprenden la caracterización física de los áridos, la determinación de las propiedades mecánicas por medio de un ensayo de trituración y, finalmente, el estudio de la microestructura de los áridos con técnicas de microscopía de barrido (SEM) y' energía dispersiva de rayos $X(E D X)$. Desde el punto de vista de resistencia mećánica los resultados indican que el mejor tipo de árido es el fabricado con un 5\% de cemento portland puzolánico. Este resultado se confirma con el análisis de la microestructura que demuestra que este tipo de árido presenta la mayor velocidad de hidratación.

\section{SUMMARY}

This study presents the results of the different tests carried out on fly' ash lightweight aggregates produced with three different kinds of binders: Lime, Portland cement and Pozzolan Portland cement. The elaboration process used for the aggregates consisted in an agglomeration system by agitation under cold bonded hardening conditions. The tests carried out were a physical characterization of the aggregates, the determination of mechanical properties with a crushing test and, finally; the study of the microstructure of the aggregates with scanning electron microscopy (SEM) and dispersive energy' $X$ ray (EDX). From the point of view of mechanical strength, the results indicate that the best kind of aggregate is the one made with a 5\% Pozzolan Portland cement. This result was confirmed by the microstructure analysis, which shows that this kind of aggregate presents the highest hydration speed.
PALABRAS CLAVE: cenizas volantes, áridos ligeros, enlace en frío, caracterización mecánica, caracterización microscópica

\section{INTRODUCCIÓN}

En el mundo se produce gran cantidad de cenizas volantes, las cuales pueden ser utilizadas de diversas formas como material de construcción, entre las que se pueden mencionar: materia prima para la fabricación de cemento, reemplazo de cemento en la elaboración de hormigón y materia prima para la producción de áridos ligeros, esta última aplicación es la que se considera en
KEYWORDS: fly ash, lightweight, aggregates, cold bonded, mechanical characterization, microscopic characterization

\section{INTRODUCTION}

The world produces a great quantity of fly ash which can be used as different forms of construction materials, anong which can be mentioned: raw materials for the cement fabrication, cement replacement for the concrete and raw materials for the production of lightweight aggregates. The latter application is the one considered in this study: The first 
este estudio. Los dos primeros campos han sido ampliamente estudiados $(1,2,3)$, sin embargo, cl tema de la fabricación de áridos ligeros, si bien se ha desarrollado de manera teórica y práctica $(4,5)$, la literatura disponible con respecto a innovaciones y/o microestructura, y su relación con las propiedades del producto final, es cscasa. Por otra parte, las técnicas más comunes para la fabricación de áridos ligeros de cenizas volantes (FALA), son las basadas en procesos hidrotérmicos y sinterizado $(4,7)$, técnicas que requieren de altos consumos energéticos. Por lo tanto, es necesario investigar acerca de las proporciones y diseño de mezclas y procedimientos de fabricación de los áridos, relacionando estas variables con las propiedades y estructura del árido que se obtiene y su posible interacción dentro de la masa del hormigón. Esta información permitiría obtener un producto que cumpla tanto con los requisitos técnicos (propiedades físicas y mecánicas), como con exigencias actuales de tecnologías limpias, con bajos consumos energéticos y mínimo impacto al medio ambiente, que favorecen el desarrollo sustentable (6).

Con el objeto de conocer y optimizar mezclas para la fabricación de FALA, se realizó la presente investigación, utilizando tecnologías limpias y tres tipos de conglomerantes.

La caracterización física de los áridos comprendió la determinación del peso específico y absorción. Las propiedades mecánicas fueron cvaluadas a través del Valor de Trituración a una carga determinada.

Finalmente, y en orden a caracterizar la microestructura de los áridos, se llevaron a cabo estudios de microscopía electrónica de barrido (SEM) y energía dispersiva de rayos $\mathrm{X}$ (EDX), realizándose un análisis desde el punto de vista del estado de hidratación de los áridos a 7 y 28 días de edad.

\section{PROCEDIMIENTO EXPERIMENTAL}

\subsection{Materiales}

Las cenizas volantes (FA) usadas en la investigación provienen de la combustión de carbón bituminoso y son generadas en la planta termocléctrica de Electroandina, Chile. Este material es recolectado por medio de precipitadores clectrostáticos. La composición química y caractcrización física de las cenizas se muestran en Tablas 1 y 2, respectivamente. Según norma ASTM C618-93, el material puede ser clasificado como ceniza Clase F. Se hicieron estudios de Difracción de Rayos X (XRD) para determinar la composición mineralógica de las cenizas volantes. two subjects have been studied in depth $(1,2,3)$; however; though the lightweight aggregate production has been developed in a theoretical and practical way $(4,5)$, the literature available with regard to innovations and/or microstructure, and its relationship with the properties of the final product, is scanty: On the other hand, the most common technologies for the production of the fly ash lightweight aggregates (FALA), are those based on hydrothermal and sintering processes $(4,7)$, which call for a high consumption of energy: Therefore, it is necessary to investigate the proportions and design of mixtures and procedures of manufacture of the aggregates, relating these variables with the properties and structure of the aggregates obtained and their possible interaction in concrete. This information would allow to obtain a product that not only meets the technical requirements (physical and mechanical properties), but also the current demands for clean technologies, with low energy consumption and minimum environmental impact which favor sustainable development (6).

In order to know and optimize mixtures for the production of FALA, the present investigation was carried out using clean technologies and three types of binders.

The physical characterization of the aggregates included determining specific gravity and absorption. The mechanical properties were evaluated through the Crushing Value at a specific load.

Finally, in order to characterize the microstructure of the aggregates, scanning electron microscopy (SEM) and energy dispersive $X$ ray $(E D X)$ were carried out, from the point of view of the hydration state of the aggregate at 7 and 28 days of age.

\section{EXPERIMENTAL PROCEDURE}

\subsection{Materials}

The Fly Ash (FA) used in the investigation was obtained from the combustion of bituminous coal generated in the thermoelectric plant of Electroandina, Chile. This material is collected by means of electrostatic precipitators. The chemical composition and physical characterization of the fly ash are shown in Tables 1 and 2, respectively: According to ASTM C618-93 standards, the fly ash can be classified as Class $F$. X-ray Diffraction (XRD) analysis was carried out to. determine the mineralogical composition of fly ash. 
TABLA 1/TABLE 1

Composición química de las cenizas volantes (Chemical analisis of fly ash)

\begin{tabular}{|l||c|c|c|c|c|c|c|c|c|}
\hline $\begin{array}{l}\text { Análisis químico } \\
\text { (Chemical composition) }\end{array}$ & $\mathrm{SiO}_{2}$ & $\mathrm{Al}_{2} \mathrm{O}_{3}$ & $\mathrm{Fe}_{2} \mathrm{O}_{3}$ & $\mathrm{CaO}$ & $\mathrm{MgO}$ & $\mathrm{SO}_{3}$ & $\mathrm{~K}_{2} \mathrm{O}$ & $\mathrm{Na}_{2} \mathrm{O}$ & $\mathrm{LOI}$ \\
\hline $\begin{array}{l}\text { Cenizas volantes (\%) } \\
\text { (Fly ash) (\%) }\end{array}$ & 56,21 & 24,40 & 5,76 & 1,70 & 0,90 & 0,07 & 0,89 & 0,01 & 5,85 \\
\hline
\end{tabular}

TABLA 2/TABLE 2

Propiedades físicas de las cenizas volantes y los conglomerantes (Physical properties of fly ash and binders)

\begin{tabular}{|l|c|c|c|}
\hline \multicolumn{1}{|c|}{$\begin{array}{c}\text { Material } \\
\text { (Material) }\end{array}$} & $\begin{array}{c}\text { Peso } \\
\text { Especifico } \\
\text { (Specific gravity) }\end{array}$ & $\begin{array}{c}\text { Superficie } \\
\text { especifica } \\
\text { (surface area) } \\
\left(\mathrm{cm}^{2} / \mathrm{g}\right)\end{array}$ & $\begin{array}{c}\text { Finura } \\
\text { (retenido sobre } \\
\text { tamiz No325, \%) } \\
\text { (Fineness retained } \\
\text { on No. 325 sieve, } \\
\%)\end{array}$ \\
\hline \hline Ceniza volante (Fly ash) & & 2,155 & 23 \\
\hline $\begin{array}{l}\text { Cemento pórtland (Portland } \\
\text { cement) }\end{array}$ & 3,176 & 2860 & 23 \\
\hline $\begin{array}{l}\text { Cemento portland puzolánico } \\
\text { (Portland pozzolan cement) }\end{array}$ & 2,969 & 4500 & \\
\hline Cal (Lime) & 2,440 & & 12 \\
\hline
\end{tabular}

Los conglomerantes empleados fueron: Cal (L), cemento Portland (P) y cemento Portland Puzolánico (PP) con un $19 \%$ de puzolana natural. En la Tabla 2 se presentan las propiedades físicas de estos materiales.

\subsection{Estudio de mezclas}

La literatura ha mencionado porcentajes de conglomerantes a usar en mezclas de cenizas volantes para la fabricación de áridos en el rango de 5\% a $10 \%$ del total en peso de material cementante $(4,8,9)$. El diseño de mezclas para el presente estudio consideró conglomerantes en dosis de 3, 5 y $7 \%$ en peso de la masa total de material cementante (ceniza volante más conglomerante).

Se desarrollaron dos ensayos con el propósito de seleccionar una mezcla óptima de acuerdo al tipo de conglomerante, estos fueron: Tiempo de Fraguado (ST) e Índice Modificado de Actividad Puzolánica (MPAI). Cada ensayo se realizó sobre 3 probetas gemelas obtenidas de cada mezcla.

El objetivo del ensayo de tiempo de fraguado fue determinar, según la dosis y tipo de conglomerante, la mezcla con el menor tiempo de fraguado. Este ensayo fue realizado de acuerdo a la norma ASTM C191-99.

Por otro lado, el Índice de Actividad Puzolánica (PAI), especificado en ASTM C311-92, permite determinar la capacidad de las cenizas volantes de fijar hidróxido de calcio $\left(\mathrm{Ca}(\mathrm{OH})_{2}\right)$, reaccionando y produciendo $\mathrm{cl}$ endurecimiento y desarrollo de resistencia mecánica cuando son mezcladas con cal. Debido a que se consideran nuevos conglomerantes para la fabricación
The binders used were: Lime $(L)$, Portland cement $(P)$ and Pozzolan Portland cement (PP) with $19 \%$ of natural Pozzolan. Table 2 shows the physical properties of these materials.

\subsection{Study of mixtures}

The literature reports the percentage of binders used in fly' ash mixtures for the production of aggregates ranging from $5 \%$ to $10 \%$ of the total weight of cementitious material $(4,8,9)$. The mixtures design for the present study considered binders in proportions of 3,5 and $7 \%$ in weight of total weight of cementitious material $(F A+$ binder $)$.

Two tests were developed with the purpose of selecting the best aggregate according to the type of binder: Setting Time (ST) and Modified Pozzolanic Activity Index (MPAI). Each test was carried out on 3 twin specimens obtained of correspond mixtures.

The objective of the setting time test was to determine the lowest setting time of the designed mixtures. This test was carried out in accordance to ASTM C191-99.

On the other hand, the Pozzolanic Activity Index (PAI) test specified in ASTM C311-92 aims to determine the fly ash capacity to fix calcium hydroxide $\left(\mathrm{Ca}(\mathrm{OH})_{2}\right)$ and therefore to harden and develop strength when mixed with Lime. Because new binders were considered for the aggregate manufacture, a Modified Pozzolanic Activity Index (MPAI) test was proposed to represent 
de áridos, se propuso un ensayo denominado Índice Modificado de Actividad Puzolánica (MPAI) con el objeto de representar el comportamiento de las mezclas a usar. El procedimiento normalizado fue modificado en los siguientes aspectos: materiales constituyentes y sus proporciones, y forma y dimensión de las probetas. No se usó arena en las mezclas por no considerarse este material en la futura fabricación de áridos. Los ensayos a compresión se realizaron sobre probetas cilíndricas de $50 \times 100 \mathrm{~mm}$. Tanto el almacenamiento de las probetas como cl procedimiento de ensayo obedecieron a las especificaciones entregadas en la norma. El requerimiento de agua de cada mezcla se determinó según procedimiento ASTM C187-98.

\section{3. Áridos ligeros de cenizas volantes}

La fabricación de áridos, se realizó por medio de un proceso de aglomeración por agitación en un plato peletizador. Los áridos frescos, o "green pellets", fucron sometidos a un proceso de endurecimiento en frío ("cold bonded"), es decir, a temperatura ambiente y expuestos a la intemperie, sometiéndolos a un sistema de curado que consistió en un rociado con agua a intervalos regulares de tiempo. Lo anterior con el objeto de reproducir las condiciones reales de una producción a escala industrial sin necesidad de consumos excesivos de energía.

Se realizaron los siguientes ensayos para determinar las propicdades físicas y mecánicas de los áridos:

\section{- Propiedades físicas. Peso específico y} absorción.

- Propiedades mecánicas. Se desarrolló el ensayo de Valor de Trituración del Árido $\left(\mathrm{ACV}_{25}\right)$ adaptado del procedimiento de norma BS 812-75. Se emplearon los mismos equipos y velocidad de aplicación de carga. Debido a la baja dureza y/o resistencia de los áridos a primeras horas de su fabricación, se consideró una carga aplicada de 25 $\mathrm{KN}$, valor que corresponde a resultados entregados en investigaciones previas sobre áridos ligeros (10). El ensayo de $\mathrm{ACV}_{25}$ se realizó a los 7 y 28 días de edad. Estos ensayos se realizaron sobre 2 muestras gemelas por tipo de árido.

Además, se realizaron estudios SEM con cl objeto de determinar el nivel de hidratación de los áridos en función del tipo de conglomerante y la edad, complementándose las observaciones con análisis EDX. Ambos ensayos se realizaron a los 7 y 28 días después de fabricados los áridos. the actual behavior of the mixes to be used. The standard procedure was modified in the following aspects: materials constituents and proportions, and specimen shape and dimension. Sand was not used in the mixes. Compressive strength tests were carried out on $50 \times 100 \mathrm{~mm}$ cylinder specimens. Storage and testing of the specimens was performed according to the specifications in the standard test. The fly ashbinder blend considered the following binders content: 3, 5 and 7\% by weight of binder. The water requirement for each mix was determined according to ASTM C187-98.

\subsection{Fly ash lightweight aggregates}

The production of FALA was made using a pan disc for fly ash agglomeration by the agitation method. The "green pellets" were submitted to a hardening process denominated "cold bonded", in other words, in outdoors exposure and temperature, subjecting it to a system of curing that consisted in spraying water at regular intervals. This was done in order to reproduce the real conditions at an industrial scale production without necessity of excessive consumption of energy.

The following tests were carried out to determine the mechanical and physical properties of the aggregates:

\section{- Physical properties. Specific gravity and absorption.}

\section{- Mechanical properties. The Aggregate Crushing} Value test $\left(A C V_{25}\right)$ was performed according to $B S$ 812-75 in what respects equipment and rate of load application. However, due to the weakness of the aggregates, a modified load of $25 \mathrm{KN}$ was considered. This decision was taken in order to allow performing the test after the first day of production of the aggregates. The load of $25 \mathrm{KN}$ was adopted based on results of previous investigations on lightweight aggregates (10). The $A C V_{25}$ test was carried out at the following ages: 7 and 28 days. These tests were performed on two twin samples by type of aggregate.

Additionally; scanning electron microscopy (SEM) analyses were also carried out to determine the degree of hydration of the aggregates as a function of binder type and age, complementing the observation with the EDX analysis. Both tests were made at 7 and 28 days of age. 


\section{RESULTADOS Y DISCUSIÓN}

\subsection{Cenizas volantes}

Los resultados del análisis de XRD (Tabla 3) muestran que la composición mineralógica de las cenizas presenta los principales compuestos necesarios para la formación de los productos de hidratación, principalmente silicato de calcio hidratado (C-S-H), compuesto fundamental para el desarrollo de resistencia mecánica de los áridos.

\section{RESULTS AND DISCUSSION}

\subsection{Fly ash}

The results of XRD studies (Table 3) show that the mineralogical composition of FA presents the main necessary compound for the formation of the hydration products, principally Calcium Silicate Hydrate ( $C-S$ $H)$, a fundamental compound in developing the mechanical strength of the aggregate.

TABLA 3/TABLE 3

Composición Mineralógica de las Cenizas Volantes (XRD) (Mineralogical composition of the fly ash (XRD))

\begin{tabular}{|l|c|}
\hline Nombre/Name & Composición/Composition \\
\hline \hline Cuarzo/Quartz & $\mathrm{SiO}_{2}$ \\
\hline Mullita/Mullite & $\mathrm{Al}_{6} \mathrm{Si}_{2} \mathrm{O}_{13}$ \\
\hline Sillimanita/Sillimanite & $\mathrm{Al}_{2} \mathrm{SiO}_{5}$ \\
\hline $\begin{array}{l}\text { Aluminato } \\
\text { tricálcico/Tricalcium } \\
\text { aluminate }\end{array}$ & $\mathrm{Ca}_{3} \mathrm{Al}_{2} \mathrm{O}_{6}$ \\
\hline Hematita/Hematite & \\
\hline
\end{tabular}

\subsection{Efecto del tipo y dosis de conglomerante sobre el comportamiento de las mezclas de cenizas volantes}

La Figura 1 muestra el efecto del tipo y dosis de conglomerante sobre la actividad puzolánica de las cenizas volantes. Se observa que, independiente del tipo de conglomerante, a mayor proporción de éste mayor es la resistencia a compresión de las mezclas de cenizas. Además, al considerar la cal como agente enlazante, se tiene que a mayor contenido de cal menor es el tiempo de fraguado. En cambio, al considerar el efecto de los cementos, los resultados indicarían que existe una dosis óptima para la cual se minimiza el tiempo de fraguado.

Con el fin de seleccionar la mejor mezcla para la fabricación de áridos se adoptó como variable de decisión el tiempo de fraguado, por presentar mayor sensibilidad que los resultados determinados por el ensayo MPAI. Se observa que para el rango comprendido entre $3 \%$ y $7 \%$ en peso de conglomerante, existe una diferencia del valor MPAI de aproximadamente $3 \mathrm{MPa}$ para cualquier tipo de conglomerante. Por otro lado, las diferencias arrojadas por el ensayo de tiempo de fraguado fluctúan entre un mínimo de 1 hora y un máximo de 6 horas para un determinado conglomerante. La mayor diferencia en los tiempos de fraguado medidos correspondió a las mezclas con cal, en cambio, las menores se presentaron al usar cemento portland puzolánico como agente conglomerante. Cabe destacar la gran diferencia entre los tiempos de fraguado medidos para la cal y los cementos; las mezclas con cal presentan tiempos de fraguado de aproximadamente $20 \mathrm{~h}$ superiores a los medidos para los cementos.

\subsection{Effect of the type and content of binder on the behavior of the fly ash mixtures}

Figure 1 shows the effect of the type and proportion of the binder on the Pozzolanic activity of FA. It is observed that, independent of binder type, the larger the binder content, the larger the compressive strength of the fly ash mixes. Also, in the case of Lime, the larger the Lime content, the smaller the setting time, while for binders based on cements the results appear to indicate that there is an optimum dosage that minimizes the setting time.

To select the best mix for aggregate manufacture the setting time was defined as the main variable because it showed a higher sensibility than the results determined by the MPAI test. It should be noted that changes of binder content between 3 to $7 \%$ wt produce a maximum change of MPAI value of almost $3 \mathrm{MPa}$ for any binder. On the other hand, a minimum and a maximum of 1 and 6 hours setting time differences were measured. The largest setting time difference corresponds to Lime binder while the minimum to Portland Pozzolan cement. Also it is worth mentioning the great difference in setting times measured for Lime and cements; Lime has almost 20 hours more setting time than cements. 


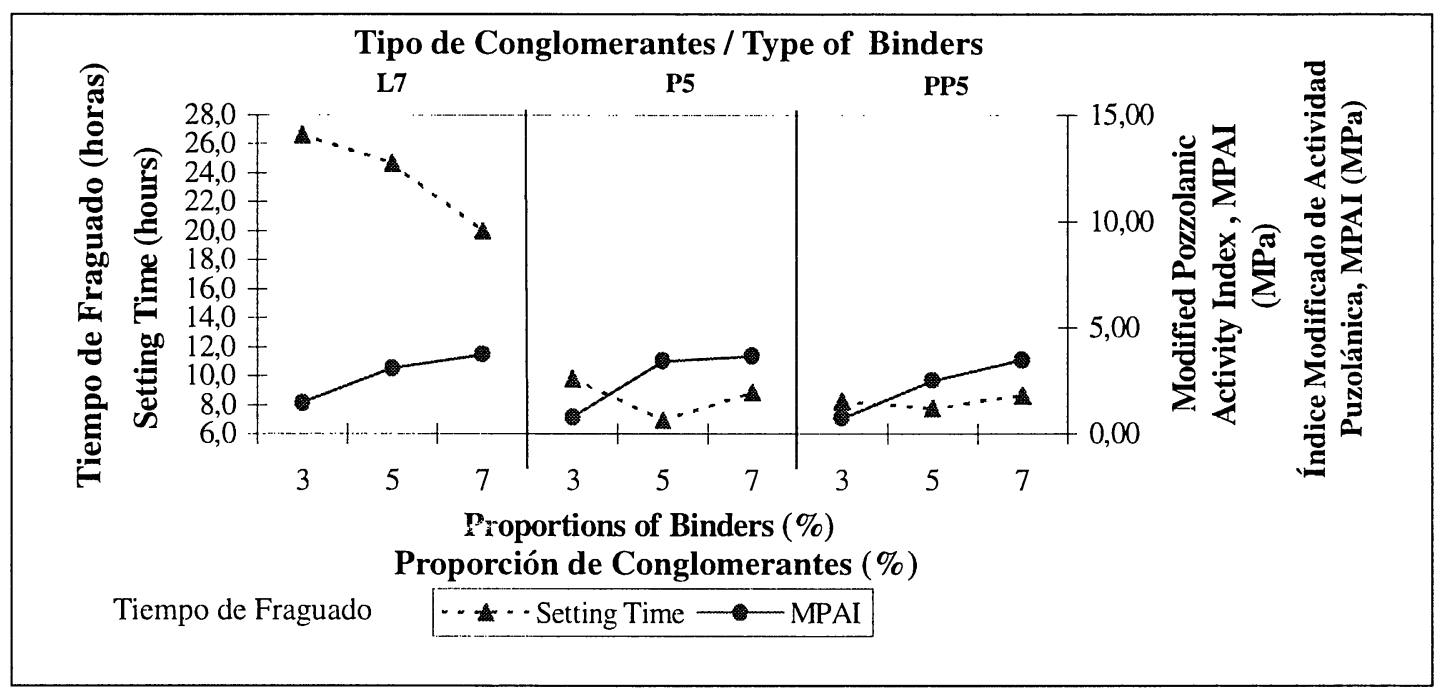

Figura 1.- Tiempo de Fraguado (ST) e Índice Modificado de Actividad Puzolánica (MPAI) para las mezclas de cenizas volantes.

Figure 1.- Setting Time (ST) and Modified Activity Index (MPAI) for the FA mixes.

Por lo tanto, de la Figura 1 se puede concluir que las dosis óptimas de conglomerante, de acucrdo al tipo considerado y tomando como referencia el menor tiempo de fraguado, son:

- F.A. $+\mathrm{Cal}=7 \%$ en peso de cal (L7).

- F.A. + cemento Portland $=5 \%$ en peso de cemento Portland (P5).

- F.A. + cemento Portland Puzolánico $=5 \%$ en peso de cemento Portland Puzolánico (PP5).

Cabe señalar que la mezcla correspondiente a L7 presenta de manera simultánea las condiciones deseadas, es decir, a menor tiempo de fraguado mayor resistencia a compresión. Sin embargo, las mezclas fabricadas con cal presentan tiempos de fraguado excesivamente largos. Por otro lado, las mezclas indicadas como P5 y PP5 no mucstran un contenido óptimo de conglomerante que cumpla simultáneamente ambas condiciones. Finalmente, los resultados sugieren que el mejor conglomerante a usar en las mezclas con cenizas volantes, desde un punto de vista técnico y económico, es el cemento Portland Puzolánico. Ello porque sumado al hecho de que presenta propiedades similares a las mezclas con cemento Portland, posee otras ventajas adicionales como son: costo inferior a los otros conglomerantes e impactos medio ambientales menores en su proceso de fabricación.

\subsection{Propiedades físicas y mecánicas de los FALA}

En la Tabla 4 se indican las características físicas de los FALA. Se observa que el peso específico se encuentra en el rango comprendido entre 1,222 y 1,274,
Therefore, from Figure 2 it can be concluded that the best binder dosage according to binder type, taking into account the smallest ST, are:

- Fly ash + Lime $=7 \%$ wt of Lime (L7)

- Fly ash + Portland cement $=5 \%$ wt of Portland cement (P5)

- Fly ash + Portland Pozzolan cement $=5 \%$ wt of Portland Pozzolan cement (PP5)

It must also be noted that the 27 mix presents the desired conditions simultaneously; i.e., a smaller the ST and a larger crushing strength of the mixture. However, mixes manufactured with Lime present excessively longer setting time. Mixes P5 and PP5 do not show an optimum binder content that simultaneously satisfies both conditions. Finally; the results suggest that the optimum binder to be used with the available fly ash from a technical and economical point of view should be Portland Pozzolan cement. This, because apart from displaying similar properties to the mixes with Portland cement, it has other additional advantages, namely, a lower cost than others binders and minimum environmental impact in the fabrication process.

\subsection{Physical and mechanical properties of FALA}

Table 4 shows the physical characteristics of FALA. It can be seen that the specific gravity is in range of 1,222 and 1,274, with a negligible difference of $4 \%$ 
existiendo una diferencia despreciable de un $4 \%$ entre el valor máximo y mínimo. Los valores obtenidos corresponden aproximadamente al $50 \%$ del peso específico de los áridos normales.

En cuanto al valor de absorción medido, se tiene que éste oscila entre $29,6 \%$ y $32,5 \%$, presentando una diferencia del orden del $10 \%$ entre ellos. Estos valores son similares al de otros áridos ligeros (piedra pómez y arcilla expandida), pero muy superiores al de los áridos normales.

En la Tabla 4 se indican, además, los resultados del ensayo de Valor de Trituración para una carga de 25 $\mathrm{KN}\left(\mathrm{ACV}_{25}\right)$ desarrollado a 7 y 28 días. El árido con mayor resistencia a la trituración tanto a 7 días como a 28 días de edad es el tipo PP5. De la tabla se desprende que a temprana edad (7 días), el valor de trituración para L7 y P5 es el mismo, siendo PP5 el árido más resistente con un valor $24 \%$ superior a las otras dos muestras. A los 28 días de endurecimiento estas diferencias aumentan, determinándose una superioridad del $50 \%$ en la capacidad para resistir trituración entre el árido más fuerte (PP5) y el más débil (L7), valor bastante considerable desde el punto de vista mecánico.

Por otro lado, el Indice de Resistencia $\left(I_{R}\right)$, que indica la velocidad de aumento de resistencia para cada tipo de árido, muestra que el árido que aumenta con mayor rapidez su resistencia a la trituración es, también, el denominado PP5, presentando un incremento del $31 \%$ entre los 7 y 28 días de edad. between the maximum and minimum value. The results correspond to 50\% of the specific gravity of the normal aggregate approximately.

Considering the measured absorption value, there is an oscillation between $29,6 \%$ and $32,5 \%$, presenting $a$ difference of $10 \%$ between them. These values are very similar to the other lightweight aggregates (pumice and expanded clay), but much higher than the normal aggregates.

Table 4 indicates, besides, the result of the Crushing Value test for a $25 \mathrm{KN}$ load $\left(A C V_{25}\right)$ developed at 7 and 28 days. The aggregate with larger crushing strength both at 7 days as well at 28 days of age is the PP5 type. The table shows that at an early age (7 days), the crushing value for L7 and P5 is the same one with PP5 being the more resistant aggregate, with a $24 \%$ value higher than the other two samples. At 28 days of hardening these differences increase, determining a $50 \%$ higher in the capacity to resist crushing between the strongest aggregate (PP5) and the weakest (L7), a considerable value from the mechanical point of view.

On the other hand, the Strength Index $\left(I_{R}\right)$, that indicates the increasing speed of the strength to each aggregate type, shows that the aggregate which increases its crushing strength at a greater speed is, also, the denominated PP5, presenting an increase of $31 \%$ between 7 and 28 days of age.

TABLA 4/TABLE 4

Propiedades físicas y mecánicas promedio de los FALA (TM=20 mm) (Physical and mechanical average properties of FALA $(T M=20 \mathrm{~mm})$ )

\begin{tabular}{|c|c|c|c|c|c|}
\hline \multirow{2}{*}{$\begin{array}{c}\text { Tipo de árido } \\
\text { (aggregate type) }\end{array}$} & \multirow{2}{*}{$\begin{array}{l}\text { Peso específico } \\
\text { (Specific gravity) }\end{array}$} & \multirow{2}{*}{$\begin{array}{c}\text { Absorción } \\
\text { (Absorption) } \\
(\%)\end{array}$} & \multicolumn{3}{|c|}{$\mathrm{ACV}_{25}(\%)$} \\
\hline & & & $\begin{array}{l}7 \text { dias } \\
\text { (7 days) }\end{array}$ & $\begin{array}{c}28 \text { dias } \\
\text { (28 days) }\end{array}$ & $I_{R}(\%)$ \\
\hline L7 & 1,222 & 32,5 & 36 & 30 & 16,6 \\
\hline $\mathrm{P} 5$ & 1,253 & 29,6 & 36 & 27 & 25,0 \\
\hline PP5 & 1,274 & 32,2 & 29 & 20 & 31,0 \\
\hline
\end{tabular}

\subsection{Estudio de Microscopia Electrónica de Barrido (SEM) y Microanálisis de Energía Dispersiva de Rayos X (EDX) sobre áridos de cenizas volantes}

Los estudios de microscopía permitieron establecer claras diferencias en los estados de hidratación de cada uno de los áridos fabricados.

\subsection{Scanning Electronic Microscopy (SEM) and Energy dispersive X-Ray (EDX) on FALA}

The microscopy studies allowed establishing clear differences in the hydration state of each one of the aggregates manufactured. 
Como se muestra en la Figura 2, los áridos tipo P5 presentan a los 7 días una zona superficial con macroestructuras cristalinas que se asemejan a la estructura de los cristales de portlandita $(11,12)$, hipótesis que se confirma por medio del análisis EDX que evidencia una importante presencia de $\mathrm{Ca}$, con bajas proporciones de Si y Al. Por otra parte, un análisis interior del árido (Figura 3) muestra la aparición de productos de hidratación de morfología ciliar, propia de las estructuras de C-S-H (silicato de calcio hidratado) $(13,14)$. Los productos de hidratación presentes en estas imágenes son ricos en $\mathrm{Ca}$, Si y $\mathrm{Al}$, lo que confirmaría la presencia de C-S-H alrededor de las partículas de cenizas volantes $\mathrm{y}$, posiblemente, la formación de portlandita. En ambos casos se obscrvan partículas de cenizas volantes no hidratadas, las que se identifican por su morfología característica constituida por partículas esféricas (3, 13). Vale destacar que los análisis SEM han permitido evidenciar gran cantidad de vacíos entre los compuestos de hidratación(vacíos capilares), del orden de 1 a $5 . \mu \mathrm{m}$, e incluso de $10 \mu \mathrm{m}$.

A los 28 días se observa un aumento en la densidad de las macroestructuras cristalinas presentes en la zona superficial, las que son ricas en $\mathrm{Ca}, \mathrm{Si}$ y $\mathrm{Al}$, estos dos últimos compuestos en mayor proporción que el caso anterior. Sin embargo, aún aparecen vacíos considerables de un tamaño aproximado a $3 \mu \mathrm{m}$ (Figura 4). Hacia el centro del árido se evidencia un notorio aumento en la densidad de los productos de hidratación, observándose la presencia de cristales en forma de agujas, o cstructuras aciculares, lo que indicaría la presencia de ettringita $(12,13)$. El análisis EDX revela la existencia de $\mathrm{Al}$, $\mathrm{Ca}, \mathrm{Si}$ y $\mathrm{S}$ en menor cantidad, lo que avala la presencia de ettringita, acompañada de otros productos de hidratación, en este caso C-S-H. Se observa una distribución más homogénea de los productos de hidratación, siendo estos superiores en la zona externa y disminuyendo hacia el interior del árido. El análisis EDX indica la presencia de $\mathrm{Si}, \mathrm{Al}$ y $\mathrm{Ca}$ como elementos predominantes en el centro del árido, presentándose una morfología similar a la observada en la zona externa a la edad de 7 días (Figura 5). Estas observaciones permiten concluir que los estados de hidratación avanzan desde el exterior hacia el interior del árido, lo que se debería al sistema de curado de los áridos que consiste en un rociado superficial con agua a intervalos regulares de tiempo. Este aporte de humedad favorecería las reacciones de hidratación en la superficie.

Los áridos fabricados con cemento portland puzolánico (PP5), presentan una estructura más homogénea a los 7 días, sin una presencia tan evidente de vacíos, aspecto beneficioso desde el punto de vista de la resistencia mecánica. En la zona
As shown in Figure 2, the aggregate type P5 presents at 7 days a superficial area with crystalline macrostructure that resembles the crystals of portlandite structure. $(11,12)$, an hypothesis that is confirmed by means of the EDX analysis evidencing an important presence of $\mathrm{Ca}$, with low proportions of $\mathrm{Si}$ and Al. On the other hand, an interior analysis of the aggregate (Figure 3) shows the appearance of hydration products with ciliary morphology, characteristic of the structures of $C-S-H$ (calcium silicate hydrate) $(13,14)$. The hydration products present in these images are rich in $\mathrm{Ca}$, Si and $A l$, that confirm the presence of $C-S-H$ around the particles of $F A$ and possibly the portlandite formation. In both cases FA particles that are not hydrated are observed, identified by their characteristic morphology constituted by' spherical particles (3, 13). It is worth mentioning that the SEM analysis has allowed to evidence a great quantity of voids among the hydration compound (capillary voids), of the order of 1 to $5 \mu \mathrm{m}$, and even of $10 \mu \mathrm{m}$.

At 28 days an increase in the density of the crystalline macrostructure present in the superficial area is observed; they are rich in $\mathrm{Ca}$, Si and Al, the latter two elements in larger proportion that the previous one. However, there still appear considerable voids of $3 \mu \mathrm{m}$ size (Figure 4). Towards the center of the aggregate there is a notorious increase in the density of the hydration product, and the presence of glassy structures in the form of needles, or acicular structure, is observed that would indicate the presence of ettringite (12,13). The EDX analysis reveals Al, Ca, Si and $S$ in smaller amounts, which confirms the presence of ettringite, accompanied by other hydration products, in this case $C-S-H$. A more homogeneous distribution of the hydration products is observed, with these being greater in the external zone and decreasing to the interior of the aggregate. The EDX analysis indicates the presence of Si, Al and Ca as predominant elements in the center of the aggregates, presenting $a$ morphology similar to the one indicated in the external zone at the age of 7 days (Figure 5). These observations allow concluding that the state of hydration advances from the exterior to the interior of the aggregate, as a product of the curing system that consists of a superficial water spraying at regulars intervals of times. This contribution of humidity favors the hydration reactions on the surface.

The aggregates manufactured with Portland Pozzolan cement (PP5), present a more homogeneous structure at 7 days, without an obvious presence of voids, a beneficial aspect from the point of view of mechanical strength. A network rich in Si, Al and Ca (figure 6) can 
externa se observan redes ricas en $\mathrm{Si}, \mathrm{Al}$ y $\mathrm{Ca}$ (Figura 6). Estas estructuras son la base para los cristales de C-S-H, principales compuestos que otorgan resistencia a las pastas de cemento y que, en este caso, estarían otorgando resistencia a la pasta de cenizas volantes. Se observan cristales tanto de forma hexagonal como acicular los que se componen de elementos de $\mathrm{Ca}, \mathrm{Al}$, Si y $\mathrm{S}$ en menor cantidad, lo que indica la presencia de cristales de portlandita y, posiblemente, monosulfatos $\left(\mathrm{AF}_{\mathrm{m}}\right) \mathrm{o}$ ettringita $\left(\mathrm{AF}_{\mathrm{f}}\right)$. Hacia el centro del árido se observan estados de hidratación similares, con gran presencia de partículas de cenizas volantes que actúan como centros de nucleación para productos ciliares ricos en $\mathrm{Si}, \mathrm{Al}$ y $\mathrm{Ca}$, permitiendo establecer nuevamente la formación de estructuras de C-S-H (Figura 7). Vale destacar que se observan espacios vacíos, los que sin embargo son menores a los detectados en los áridos P5, situación que, como se mencionó anteriormente, refuerza la mayor resistencia a la trituración ofrecida por este tipo de árido.

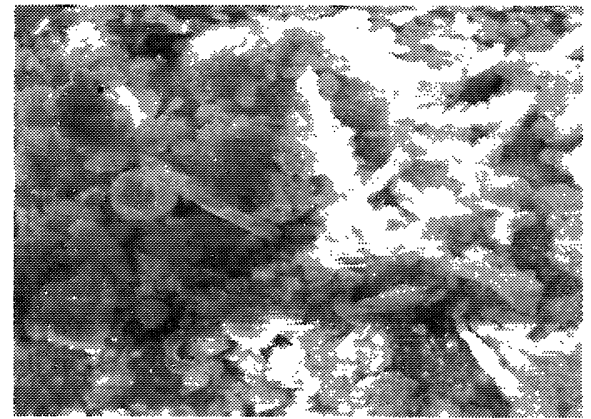

Figura 2.- Micrografía x 2000, árido P5 a 7 días, zona superficial. Figure 2.- Micrograph $\times 2000$, P5 aggregate at 7 days, superficial area.

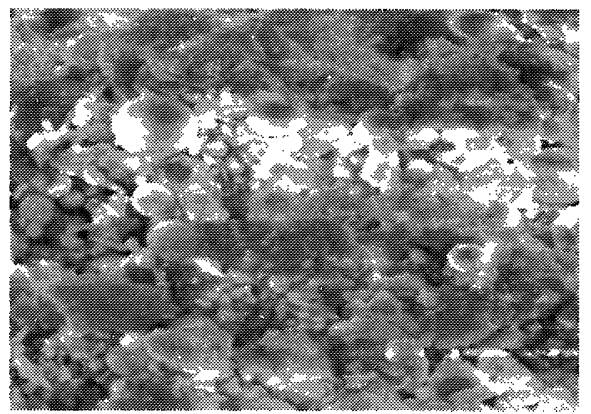

Figura 4.- Micrografía x 2000, árido P5 a 28 días, zona superficial. Figure 4.- Micrograph $\times 2000$, P5 aggregate at 28 days, superficial area.

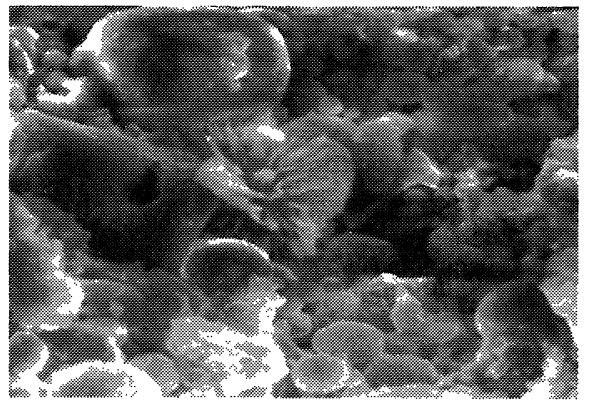

Figura 6.- Microgralía x 2000, árido PP5 a 7 días, zona superficial. Figure 6.- Micrograph x 2000, PP5 aggregate at 7 days, superficial area. be observed in the external zone. Those structures are the basis for the crystal of $C-S-H$, principal compounds that give the strength of the cement paste, and in this case would be giving strength to the FA paste.

Hexagonal and acicular forms of glasses are observed, composed of elements of $\mathrm{Ca}, \mathrm{Al}, \mathrm{Si}$ and $\mathrm{S}$ to a lesser degree, indicating the presence of portlandite crystal and possibly monosulfates $\left(A F_{m}\right)$ or

ettringite $\left(A F_{t}\right)$. Toward the center of the aggregate, $a$ similar hydration state is observed, with a great presence of FA particles acting as nucleation centers for ciliar products rich in $\mathrm{Si}, \mathrm{Al}$ and $\mathrm{Ca}$ that allow to establish once again the formation of the structure of $C-S$-H (Figure 7). It is worth mentioning that empty spaces are observed which, however, are smaller that those detected in the P5 aggregates, a situation which, as mentioned previously, further adds to the greater compressive strength offered by this kind of aggregate.

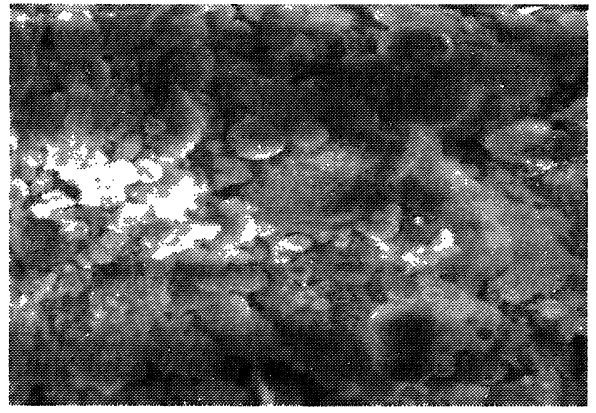

Figura 3.- Micrografía x 2000, árido P5 a 7 días, zona interior.

Figure 3.- Micrograph $x 2000$, P5 aggregate at 7 days, interior area.

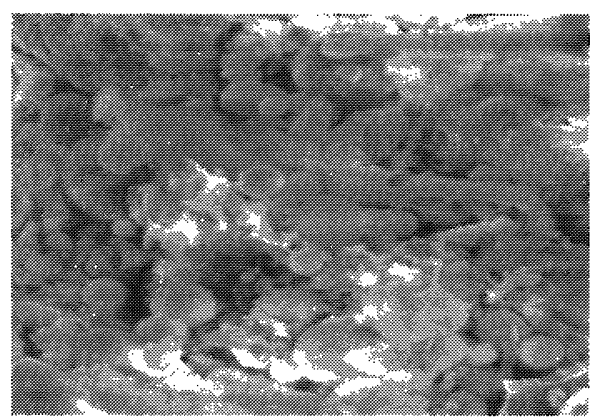

Figura 5.- Micrografía x 2000, árido P5 a 28 días, zona interior. Figure 5.- Micrograph x 2000, P5 aggregate at 28 days, interior area.

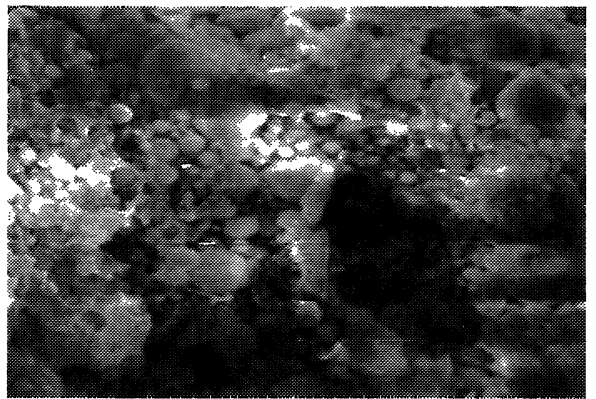

Figura 7.- Micrografía x 2000, árido PP5 a 7 días, zona interior.

Figure 7.- Micrograph $x$ 2000, PP5 aggregate at 7 days, interior area. 
A los 28 días de edad la densidad de los productos de hidratación de los áridos PP5 es considerablemente superior a la observada para las estructuras de P5 a igual edad (comparar Figura 4 y Figura 8). En la Figura 8 se observan densas estructuras cristalinas de morfología hexagonal, acompañadas de macroestructuras cristalinas. Según análisis de EDX estos productos de hidratación estarían compuestos por $\mathrm{Ca}, \mathrm{S}, \mathrm{Al}$ y $\mathrm{Si}$, siendo el Ca el elemento más abundante, lo que nos lleva a confirmar la presencia importante de portlandita $\left(\mathrm{Ca}(\mathrm{OH})_{2}\right)$ y C-S-H, con un alto nivel de reacción y aportando de manera considerable a la resistencia superficial del árido. Finalmente, se estima la presencia de monosulfato hidratado $\left(\mathrm{AF}_{\mathrm{m}}\right)$, cuya morfología también corresponde a cristales hexagonales (13) y que posee entre sus constituyentes azufre. En Figura 9 se observa la zona interna del árido, que presenta gran cantidad de productos de hidratación con cristales de portlandita, ricos en $\mathrm{Ca}$, y estructuras ciliares rodeando las partículas de cenizas volantes. Dichas estructuras corresponderían a C-S-H debido a la abundante pressencia de Si detectada por medio del análisis de EDX. Por otro lado, se detectan cristales en forma de aguja que indicarían la existencia de estructuras de ettringita, hecho concordante con la presencia de $\mathrm{Al}$ y $\mathrm{S}$ arrojada del análisis. Nuevamente es posible concluir que los estados de hidratación más avanzados se presentan en las regiones exteriores, aspecto muy conveniente desde el punto de vista de eficacia de los áridos, es decir, resistencia a la solicitación de cargas externas.

Las estructuras cristalinas presentes en los áridos tipo L7, evidencian la menor velocidad de hidratación con respecto a los otros dos tipos de muestras consideradas. En la Figura 10 se muestran productos hidratados similares a los observados en P5 a igual edad (Figura 2), es decir, 7 días. Se aprecian numerosas partículas de cenizas volantes que mantienen su morfología esférica, lo que indica que la reacción puzolánica a esta edad es aún muy baja, situación observada además en la zona interior del árido (Figura 11). Se siguen observando vacíos, aunque inferiores a
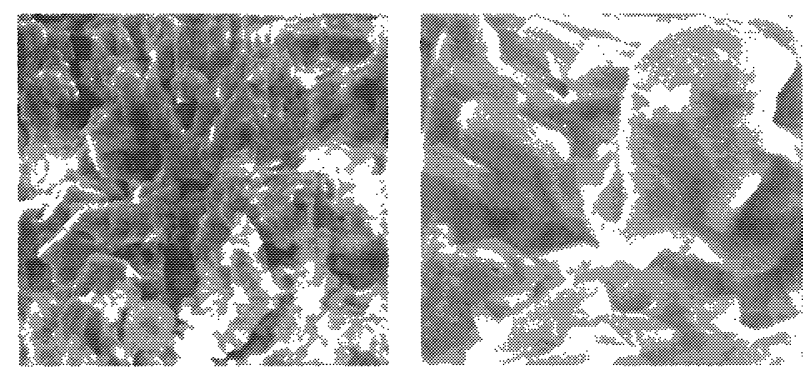

a)

Iتigura 8.- Micrografía árido PP5 a 28 días, zona superficial. a) x 200(), b) $\mathrm{x} 5000$.

Figure 8.- Micrograph PP5 aggregate at 28 dans, superficial area. a) $\times 2000$, b) $\times 5000$.
At 28 days of age the density of the hydration products of the PP5 aggregate is considerably higher than the one observed for the P5 structures at the same age (compare Figure 4 and Figure 8). Figure 8 shows dense crystal structures of hexagonal morphology, accompanied by crystalline macrostructure. According to the EDX analysis these hydrated products would be made up by $C a, S, A l$ and Si, where Ca is the most abundant element, leading us to infer the important presence of portlandite $\left(\mathrm{Ca}(\mathrm{OH})_{2}\right)$ and $\mathrm{C}-\mathrm{S} \mathrm{H}$, with a high reaction level and contributing to a considerable degree to the superficial strength of the aggregate. Finally, the presence of monosulfate hydrate $\left(A F_{m}\right)$ is assumed, whose morphology also corresponds to hexagonal glasses (13) and that has sulfur among its constituents. In Figure 9 the internal area of the aggregate is observed, presenting a great quantity of hydrated products with portlandite crystal rich in $\mathrm{Ca}$ and ciliar structures surrounding the particles of FA. These structures would correspond to $C-S-H$ due to the abundant presence of Si detected by means of the EDX analysis. On the other hand, crystal in the form of needles are detected that would indicate the existence of ettringite structures which agrees with the presence of Al and S. Again it is possible to conclude that the most advanced hydration states are present in the external regions, a very convenient aspect from the point of view of the effectiveness of the aggregate,i.e. compressive strength of external loads.

The crystalline structures present in type L7aggregates evidence the lower hydration speed with respect to the other 2 types of samples considered. Figure 10 shows hydrated products similar to those observed in P5 at the same age (Figure 2), that is, 7 days. A great number of FA can be seen retaining their spherical morphology, which indicates that the Pozzolan reaction at this age is still very low, a situation also observed in the interior zone of the aggregate (Figure 11). It keeps showing voids, but smaller that those seen before in P5. Ciliar structures made up by $\mathrm{Si}, \mathrm{Al}$ and Ca surrounding the FA

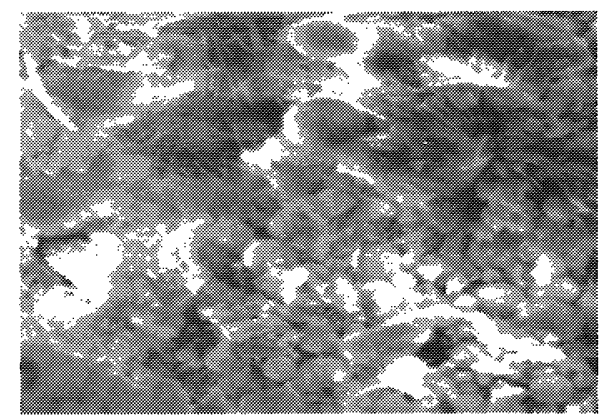

Figura 9.- Micrografía x 2000, árido PP5 a 28 días, zona interior. Figure 9. - Micrograph $\times 2000$, PP5 aggregate at 28 days, interior area. 


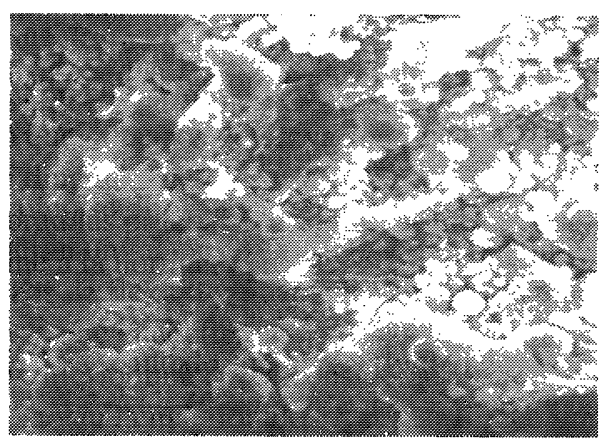

Figura 10.- Micrografía x 2000, árido L7 a 7 días, zona externa.

Figure 10.- Micrograph $\times 2000$, L.7 aggregate at 7days, external area.

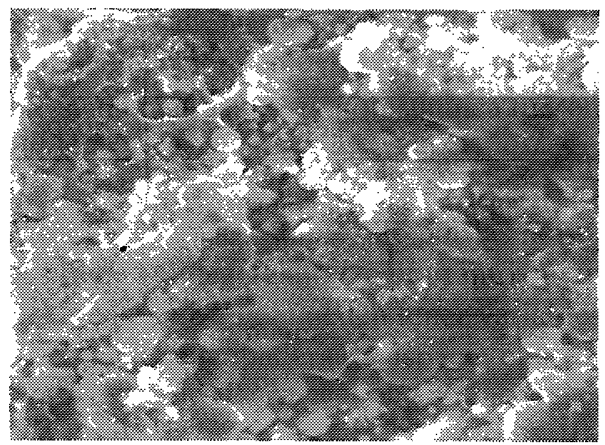

Figura 12.- Micrografía x 2000, árido L7 a 28 días, zona externa.

Figure 12.- Micrograph $\times 2000$, L7 aggregate at 28 days, external area.

los presentados en P5. Se aprecian estructuras ciliares compuestas de $\mathrm{Si}, \mathrm{Al}$ y Ca rodeando las partículas de cenizas volantes, estas estructuras corresponderían a compuestos de C-S-H en estado inicial de reacción.

A los 28 días aparecen productos de hidratación más densos pero aún se identifican numerosas partículas de cenizas volantes sin reaccionar y vacíos del orden de $5 \mu \mathrm{m}$ entre partículas (Figuras 12 y 13). Destacar que la microestructura de este tipo de árido presenta un estado de hidratación muy homogéneo a través de toda su sección, sin presentar diferencias notorias entre el exterior e interior. Esto podría explicar el menor $\mathrm{I}_{\mathrm{R}}$ mencionado en el apartado 3.3, ya que no se cuenta con la influencia favorable del estado de hidratación más avanzado de la zona exterior que otorgaría mayores resistencias superficiales.

Finalmente, al observar y comparar el borde exterior de los áridos, en un corte transversal (Figuras 14 y 15), es posible identificar una especie de costra externa, de mayor densidad o menor índice de poros, que los recubre. En la Figura 14 se muestra una ampliación de esta zona característica, a los 7 días de

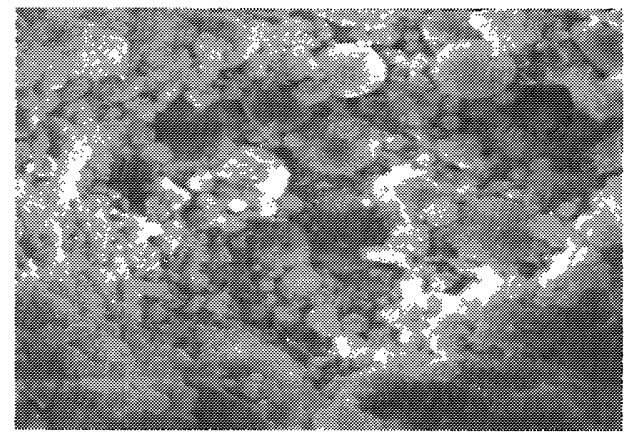

Figura 11.- Micrografía x 2000, árido $\mathrm{L} 7$ a 7 días, zona interior.

Figure 11.- Micrograph x 2000, L7 aggregate at 7days, interior area.

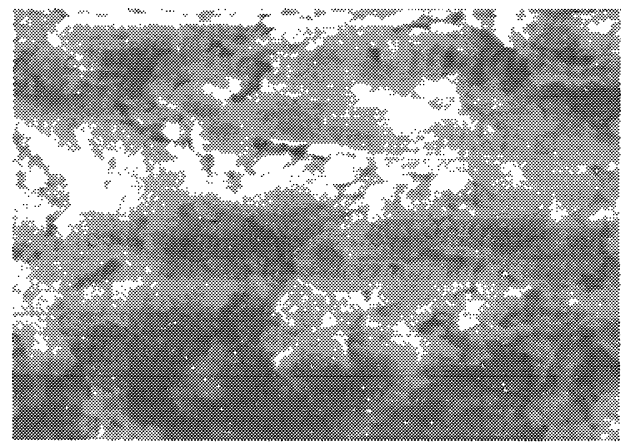

Figura 13.- Micrografía x 2000, árido L77 a 28 días, zona interior.

Figure 13.- Micrograph $\times 2000$, L7 aggregate at 28 days, interior area.

particles can be appreciated; these structures correspond to $\mathrm{C}-\mathrm{S}-\mathrm{H}$ compounds in an initial state of reaction.

At 28 days more dense hydration products appears but still many FA particles without any reaction and voids in the order of $5 \mathrm{~mm}$ between particles are still identified (Figure 12 and 13). It is worth mentioning that the microstructure of this type of aggregate presents a very homogeneous state of hydration through all its section, without presenting notorious differences between the exterior and interior. This could explain the lower $I_{R}$ reported in item 3.3, because it does not have the favorable influence of the most advanced hydration state in the external area that would afford greater superficial strength.

Finally, when we observe and compare the external border of the aggregates, in cross-section (Figure 14 and 15), it is possible to identify a kind of an external coat, of bigger density or smaller pores index that covers it. Figure 14 shows an amplification of this characteristic area at 7 days of age, with a thickness of 


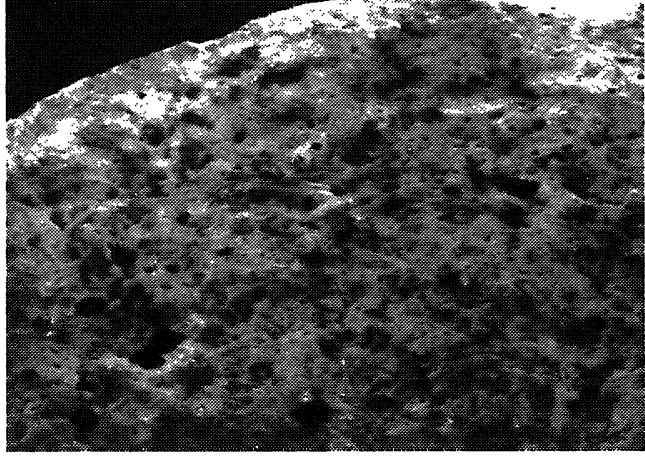

Figura 14.- Micrografía x 35, costra superficial a 7 días.

Figure 14.- Micrograph $\times 35$, superficial crust at 7 days.

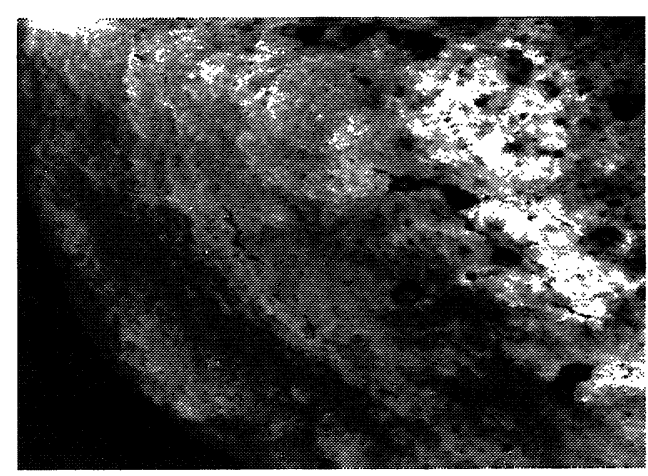

Figura 15.- Micrografía x 35, costra superficial a 28 días.

Figure 15.- Micrograph $x 35$, superficial crust at 28 days. edad, determinándose un espesor de la costra de aproximadamente $150 \mu \mathrm{m}$. En la Figura 15 se muestra la misma zona pero a 28 días de edad, observándose que el espesor de esta especie de recubrimiento alcanza los $1.000 \mu \mathrm{m}$ aproximadamente. Esta observación reafirma la conclusión de que el aporte de humedad, proporcionado por el sistema de curado empleado, favorece la hidratación de la superficie de los áridos, generando un sello superficial más resistente.

En resumen, se puede establecer que los mecanismos de hidratación son similares en cada uno de los áridos analizados, pero se generan diferencias tanto en las velocidades de reacción como en el contenido de poros. Los áridos fabricados con cemento portland puzolánico se caracterizan por una mayor velocidad de hidratación con gran presencia de $\mathrm{Ca}$ y $\mathrm{Si}$, lo que indica la presencia de $\mathrm{C}-\mathrm{S}-\mathrm{H}$, compuesto fundamental para la ganancia de resistencia mecánica de las pastas, en este caso de cenizas volantes. Los autores confirman que el mayor grado de hidratación presentado en este tipo de árido se debe, en gran medida, a dos factores principales. En primer lugar, a la mayor finura que presenta el conglomerante cemento portland puzolánico, representado por la superficie específica Blaine (Tabla 2). En segundo término, debido al hecho de que las reacciones puzolánicas, es decir, la fijación de hidróxido de calcio, son más rápidas cuando provienen del proceso de hidrólisis del cemento.

Por otro lado, se detectó un menor contenido de poros en los áridos PP5, los cuales presentan además tamaños menores. Lo dicho anteriormente también se debería al mayor grado de hidratación alcanzado con el conglomerante cemento portland puzolánico, el cual genera productos de hidratación que llenan los vacíos capilares. Cabe destacar que todos los áridos se caracterizan por presentar una especie de costra exterior, la cual se originaría debido al sistema de curado diseñado para el producto. the coat of approximately $150 \mu \mathrm{m}$. Figure 15 shows the same area but at 28 days of age, and the thickness of this kind of coal reaches $1.000 \mu \mathrm{m}$ approximately. This observation reaffirms the conclusion that the contribution of humidity, provided by the system of curing resorted to, favors the hydration of the aggregates surface, generating a stronger superficial coat.

Summing up, the hydration mechanisms are similar in each one of the aggregates analyzed, but there are differences generated in the reaction speeds as in the content of pores. The aggregates manufactured with Pozzolan Portland cement are characterized by $a$ larger hydration speed with greater presence of $\mathrm{Ca}$ and $\mathrm{Si}$, indicating the presence of $\mathrm{C}-\mathrm{S}-\mathrm{H}$, compound fundamental for the gain of mechanical strength of the pastes, in this case of FA. The authors posit that the greatest degree of hydration presented in this type of aggregates is due to a great extent to two main factors. First, to the largest fineness that Pozzolan Portland cement binder presents, represented by the Blaine specific surface (Table 2). And second, to the fact that the Pozzolan reactions, i.e., fixing of calcium hydroxide, are faster when they derive from the process of hydrolysis of the cement.

On the other hand, a lower content of pores was detected in the PP5 aggregates, which also presents smaller sizes. This would also be due to the largest degree of hydration reached with the pozzolan portland cement binder, the one that generates hydration products that fill the capillary void. It is worth mentioning that all the aggregates are characterized by presenting a kind of an external coat, which would originate due to the system of curing designed for the product. 


\section{CONCLUSIONES}

De los ensayos y resultados obtenidos sobre los áridos fabricados con cenizas volantes es posible determinar lo siguiente:

- Los ensayos de caracterización física permiten clasificar el producto desarrollado como árido ligero.

- Los áridos poseen un alto valor de absorción, el cual es similar a otros áridos ligeros, tales como piedra pómez y arcilla expandida

- Las propiedades mecánicas de los FALA, indican que el tipo de árido que cumple mejor los requisitos de resistencia a la trituración es el tipo PP5, fabricado con un $5 \%$ en peso de cemento portland puzolánico. Se determina que éstos ofrecen una resistencia a la trituración superior, tanto a los 7 días como a los 28 días de edad.

- A los 28 días, la resistencia a la trituración de los áridos PP5 es superior en un 35\% y 50\% con respecto a los áridos fabricados con cemento portland y cal, respectivamente.

- La mayor resistencia a la trituración de los áridos PP5 viene asociada con un leve incremento de su peso específico, diferencia que sin embargo es despreciable.

- De las observaciones realizadas por medio de SEM, es posible concluir que dado el estado de hidratación y la morfología y composición de los productos de hidratación, el tipo de árido que ofrece las mayores ventajas para la elaboración de áridos, en condiciones de endurecimiento en frío, son los fabricados con cemento portland puzolánico.

- Dadas las características de las reacciones puzolánicas, se plantea que es posible esperar que el empleo de los áridos discutidos en este trabajo permita obtener un hormigón de características más homogéneas que el fabricado con áridos naturales. Las potenciales reacciones que ocurrirían en la zona de transición, o interfase, podrían reducir sustancialmente el hidróxido de calcio, compuesto que debilita dicha zona, siendo reemplazado por compuestos de C-S-H, producto que daría una característica resistente y homogénea a la zona en cuestión.

- Se plantea que la principal ventaja de usar cemento como agente conglomerante, en vez de cal, sería la mayor rapidez en la fijación del hidróxido de calcio producto de la hidrólisis del cemento, lo que reportaría una hidratación más rápida de la pasta de cenizas volantes. Por otro lado, el mejor comportamiento tanto microestructural como mecánico de los áridos

\section{CONCLUSIONS}

From the tests and results obtained on the aggregates produced with FA it is possible to conclude the following.

- The test of physical characterization allows classifying the product developed as a lightweight aggregate.

- The aggregates have a high absorption value, similar to other lightweight aggregates, such as pumice and expanded clay.

- The mechanical properties of the FALA indicate that the aggregate type that meets the requirements of crushing strength best is the PP5 type, produced with 5\% wt of Pozzolan Portland cement. They also offer a higher crushing strength both at 7 days and at 28 days of age.

- At 28 day's, the crushing strength of the PP5 aggregate is higher by $35 \%$ and $50 \%$ with regard to the manufactured aggregate with Portland cement and Lime, respectively.

- The higher crushing strength of the PP5 aggregate is associated with a slight increase of its specific gravity, difference that however is negligible.

- From the observations carried out by means of SEM, it is possible to conclude that, given the hydration state and the morphology and composition of the hydration products, the type of aggregate that offers the best advantages for the production of aggregates, under cold bonded hardening conditions, are those manufactured with Pozzolan Portland cement.

- Given the characteristics of the Pozzolan reactions, it can be expected that the use of aggregates discussed in the paper would permit obtaining a concrete of more homogeneous characteristics than the one manufactured with natural aggregates. The potential reactions that would occur in the transition zone, or interface, could substantially reduce the calcium hydroxide, a compound that weakens this area, being replaced by compounds of $C-S-H$, a product that would give a resistant and homogeneous characteristic to the area.

- The main advantage of using cement as a binding agent, instead of lime, would be the greater speed in the fixation of the calcium hydroxide product of the hydrolysis of the cement, bringing about a quicker hydration of the FA paste. On the other hand, the best microstructural as well as mechanic behavior of the aggregates produced with pozzolan portland cement, as regards those with portland 
fabricados con cemento portland puzolánico, respecto a los con cemento portland, se debería a la mayor finura del primero. Esta propiedad otorgaría mayor capacidad de reacción y, por tanto, mayor capacidad de desarrollo de resistencias mecánicas originadas por la microestructura de los áridos.

- Finalmente, se establece que el proceso de fabricación de áridos, bajo condiciones de endurecimiento en frío, es técnicamente factible y permitc obtener un producto con claras ventajas para ser empleados como áridos ligeros para hormigón. cement, would be due to the greater fineness in the former: This property would give a larger reaction capacity; and therefore, a larger capacity to develop mechanical strength originated by the microstructure of the aggregates.

- Finally, in the process of aggregates production, under cold bonded hardening conditions, it is technically feasible to obtain a product with clear advantages for its use as a lightweight aggregate for concrete.

\section{BIBLIOGRAFÍA}

(1) Malhotra (1987). "Supplementary Cementing Materials for Concrete". SP 86-8E, Canada.

(2) Lea (1998). "Lea's Chemistry of Cement and Concrete". Fourth Edition, Ed. Peter Hewlett, Arnold Publishers, UK

(3) Joshi, R.C. and Lohtia, R.P. (1997). "Fly Ash in Concrete: Production, properties and uses", Gordon and Breach Science

Publishers, Canada.

(4) Bijen, J. (1983). "Fly ash aggregates". Proceeding International Conference: Use of Fly Ash, Silica Fume, Slag and Other Mineral by Products in Concrete"SP 79-26, Montebelo Conference, USA.

(5) Hwang, C., Lin, R., Hsu, K. And Chan, J. (1992). "Granulation of fly ash lightweight aggregate and accelerated curing technology". Proceeding Fourth International Conference: Fly Ash, Silica Fume, Slag and Natural Pozzolans in Concrete". SP 132-24, V.1, Istanbul, Turkey, 419-438.

(6) Metha, K. (1998). "Role of the pozzolanic and cementitious material in sustainable development of the concrete industry". Sixth CANMET/ACI International Conference on Fly Ash, Silica Fume, Slag and Natural Pozzolans in Concrete, may 31-june 5, Bangkok, Thailand, SP178, V.1, 1-20.

(7) Boas, A., Spanjer, J. (1985). "The manufacture and the use of artificial aggregates from fly ash produced according to the dutch cold bonded Aardelite process".

(8) Baykal, G., Ozturan, T., Savas, M., Ramadan, K. (1995). "Propertics of lightweight aggregate produced from a high calcium fly ash". Proceeding Fifth International Conference: Fly Ash, Silica Fume, Slag and Natural Pozzolans in Concrete". SP 153-15, Milwaukec, Wisconsin, USA, 269-282.

(9) Baykal, G. and Doven, A.G. (1999). Lightweight concrete production using unsintered fly ash pellet aggregate. Proceedings: $13^{\text {th }}$ International Symposium on Used and Management of Coal Combustión Products. ACAA International, January 11-15, Orlando, Florida, USA, paper 3, 1-14.

(10) Videla, C., López, M. (1999). "Dosificación de Hormigones Ligeros Estructurales”, Revista Ingeniería de Construcción, N¹9, enero-junio, 17-29.

(11) Hanehara, Sh., Tomosawa, F., Kobayakawa, M., Hwang, K. (2001). "Effects of water/powder ratio, mixing ratio of fly ash, and curing temperature on pozzolanic reaction of fly ash in cement paste". Cement and Concrete Research, V.31, $\mathrm{N}^{\circ}$ 1, january, 31-39.

(12) Xu, A. and Sarkar, Sh. (1994). "Microstructural Development in High-Volume Fly Ash Cement System". Journal of Materials in Civil Engineering, V.6, $\mathrm{N}^{\circ} 1$, feb., 117-136.

(13) Metha, K. (1986). "Concretc: Structure, properties, and materials". Ed. Prentice-Hall, USA. 